\title{
Autologous GM-CSF-Secreting Breast Cancer Vaccine
}

National Cancer Institute

\section{Source}

National Cancer Institute. Autologous GM-CSF-Secreting Breast Cancer Vaccine. NCI

Thesaurus. Code C82388.

An autologous tumor cell vaccine containing irradiated breast cancer cells transfected with the granulocyte macrophage-colony-stimulating factor (GM-CSF) gene with potential antineoplastic activity. Autologous breast cancer cells are transduced ex vivo with an adenovirus vector encoding the GM-CSF gene and irradiated and then reintroduced into the patient. Upon repeated subcutaneous administration of the vaccine, autologous GM-CSF-secreting breast cancer cells secrete GM-CSF, which may stimulate a tumor-specific cytotoxic T-lymphocyte $(C T L)$ response. 